\title{
pH induced elastic modulus of guard cell wall in stomatal movement
}

\author{
YANG Yi ${ }^{1,2}$, ZHAO Yang ${ }^{2} \&$ ZHU GuoLi ${ }^{2 *}$ \\ ${ }^{1}$ Environment and Plant Protection Institute, Chinese Academy of Tropical Agricultural Sciences; Key Laboratory of Monitoring and Control of \\ Tropical Agricultural and Forest Invasive Alien Pests, Ministry of Agriculture; Hainan Key Laboratory for Monitoring and Control of Tropical \\ Agricultural Pests, Danzhou 571737, China; \\ ${ }^{2}$ State Key Laboratory of Plant Physiology and Biochemistry, College of Biological Sciences, China Agricultural University, Beijing 100193, \\ China
}

Received June 15, 2011; accepted August 5, 2011

\begin{abstract}
Guard cell wall properties are important in stomatal movement. Previous research focused on the structure and anatomy of guard cell walls, but little is known about the physical changes that take place within the walls during stomatal opening and closure. In this work, we investigate the volumetric elastic modulus $(\varepsilon)$ of the guard cell wall at different $\mathrm{pH}$ values during stomatal opening in Vicia faba epidermal strips using a cell pressure probe. The volumetric elastic modulus of the guard cell wall decreased from 7.098 to $5.690 \mathrm{MPa}$ when the $\mathrm{pH}$ of the cell wall decreased from 8.60 to 6.50 . It is easier for guard cells to change their volume at a lower volumetric elastic modulus during stomatal movement. The results are suggestive of a putative role for $\mathrm{pH}$ in the regulation of stomatal movement.
\end{abstract}

volumetric elastic modulus, guard cell wall, cell pressure probe, $\mathrm{pH}$, stomatal movement

Citation: Yang Y, Zhao Y, Zhu G L. pH induced elastic modulus of guard cell wall in stomatal movement. Chinese Sci Bull, 2011, 56: 3554-3557, doi: 10.1007/s11434-011-4798-Z

It is well known that stomata are important to land plants. Opening and closing of stomatal pores serve a vital physiological function, which in turn affect photosynthesis, transpiration and respiration. Stomata are bounded by a pair of guard cells, which are kidney-shaped in most land plants [1]. The stomata open and close because of changes in guard cell pressure [2]. Increased turgor pressure within the guard cells leads to greater stretching of the walls in the longitudinal direction than in the tangential [3-6]. This anisotropic cell wall stretching causes the guard cells to bend away from each other and creates the stomatal pore. During stomatal movement, the guard cell wall must be exceptionally strong and show reversible deformation. Previous research focused on the structure, anatomy and molecular basis of guard cell wall functions [3-9], but little is known about the changes of physical properties in the guard cell wall during stomatal opening and closure. The volumetric elastic modulus $(\varepsilon)$ is an indicator of physical properties of the cell wall

\footnotetext{
*Corresponding author (email: glzhu2009@gmail.com)
}

[10] and its value reflects cell wall elasticity. A low $\varepsilon$ value implies a high elasticity of the cell wall and a larger change in cell volume in response to a given pressure compared with a high $\varepsilon$ value. Consequently, regulation of the volumetric elastic modulus of the guard cell wall is possibly unique and is important in the control of stomatal movement.

The cell pressure probe is a very useful tool in studies of stomatal function [11] and is used widely to study water relations of plant cells [12-14]. The probe can directly and continuously measure cell turgor pressure $(P)$, volumetric elastic modulus $(\varepsilon)$ of the cell wall, and hydraulic conductivity $\left(L_{\mathrm{p}}\right)$ of cell membranes in single cells of higher plants. Therefore, use of the cell pressure probe to measure the volumetric elastic modulus of the guard cell wall can help us to understand the regulation of stomatal movement.

$\mathrm{pH}$ is a key regulatory component in stomatal movement. Elevated $\mathrm{pH}$ can induce stomatal closure $[15,16]$, and abscisic acid (ABA) treatment can increase cytoplasmic $\mathrm{pH}$ [17]. However, the influence of $\mathrm{pH}$ on the physical proper- 
ties of guard cell walls is poorly understood.

In this paper we use a previously described cell pressure probe technique [11-14] to explore the volumetric elastic modulus of guard cell walls during stomatal movement in Vicia faba epidermal strips. The results show that reduction in $\mathrm{pH}$ can decrease the volumetric elastic modulus of the guard cell wall.

\section{Materials and methods}

\subsection{Plant material}

Plants of Vicia faba L. were grown in an environmentally controlled greenhouse at $40 \%-60 \%$ relative humidity, and under a $14 \mathrm{~h}$ light $\left(23^{\circ} \mathrm{C}, 06: 00-20: 00\right) / 10 \mathrm{~h}$ dark $\left(16^{\circ} \mathrm{C}\right.$, 20:00-06:00) photoperiod at 80-100 $\mu \mathrm{mol} \mathrm{m}^{-2} \mathrm{~s}^{-1}$ at plant height provided by metal halid lamps.

\subsection{Incubation of epidermal strips and measurement of stomatal apertures}

The first fully expanded leaf on the main axis of 3- to 4-week-old plants was excised. Epidermal strips were peeled from the excised leaves and immersed in low $\mathrm{pH}$ buffer (10 mmol L ${ }^{-1}$ Mes/Tris, $\mathrm{pH}$ 6.50) or high $\mathrm{pH}$ buffer (10 mmol L ${ }^{-1}$ Hepes/Tris, $\mathrm{pH} 8.60$ ) for $30 \mathrm{~min}$ in the light, with occasional shaking to remove air bubbles. After $30 \mathrm{~min}$, the epidermal strips were mounted, cuticle upwards, on a culture dish with sticky tape and the culture dish was filled with $\mathrm{pH}$ buffer. The stomatal apertures were measured under a microscope fitted with an ocular micrometer.

\subsection{P and $\varepsilon$ measurements}

The cell turgor pressure $(P)$ and the volumetric elastic modulus $(\varepsilon)$ measurements were performed using the cell pressure probe as described previously $[11,12]$. To estimate $\varepsilon$ according to the equation $\varepsilon=V \cdot \Delta P / \Delta V$ [18], the guard cell volume $(V)$ was taken as a constant over the small pressure impulse $(0.03-0.05 \mathrm{MPa})$, and $V$ was approximated by the guard cell volume at full turgor pressure. The value of $\varepsilon$ was determined in small pressure impulses by measurement of changes in turgor pressure $(\Delta P)$ in response to small changes in cell volume $(\Delta V)$ with the aid of the pressure probe. $V$ was measured using a microscope fitted with an ocular micrometer, and small guard cell volume $(\Delta V)$ changes were measured from the changes of the meniscus position in the microcapillary tip of the cell pressure probe.

\section{Results}

\subsection{Volumetric elastic modulus of the guard cell wall at pH 8.60}

After pretreatment of the epidermal strips with solutions of
$\mathrm{pH} 8.60$ in the light, the stomatal aperture (Table 1) and guard cell volume $(V)$ were measured and calculated under a microscope (Figure 1(a)). When the guard cell was punctured with the microcapillary tip of the cell pressure probe, the guard cell turgor pressure compressed the silicone oil in the measuring system so that a meniscus is formed in the tip of the microcapillary tube between the cell sap and silicone oil (Figure 1(b)). The position (position 1; Figure 1(c)) of the meniscus was kept constant with the aid of the probe so that the cell turgor pressure $(P)$ (Table 1) could be measured. When turgor was steady, the meniscus rapidly shifted to a different position (position 2; Figure 1(d)), which caused a decrease in turgor pressure $(\Delta P)$. The corresponding volume change $(\Delta V)$ was also measured so that the elastic modulus ( $\varepsilon$ ) (Table 1) could be calculated.

\subsection{Volumetric elastic modulus of the guard cell wall at pH 6.50}

After pretreatment of the epidermal strips with solutions of $\mathrm{pH} 6.50$ in the light, the stomatal aperture (Table 1) and guard cell volume $(V)$ were measured and calculated under a microscope (Figure 2(a)). When puncturing the guard cell with microcapillary of the cell pressure probe, the guard cell turgor pressure compressed the silicone oil in the measuring system so that a meniscus is formed in the tip of the microcapillary between cell sap and silicone oil (Figure 2(b)). The position (position 1) (Figure 2(c)) of the meniscus was kept constant with the aid of the probe so that the cell turgor pressure $(P)$ (Table 1) can be measured. When turgor was steady, the meniscus was rapidly shifted to a different position (position 2) (Figure 2(d)) which caused a decrease in turgor pressure $(\Delta P)$. The corresponding volume change $(\Delta V)$ was also measured so that the elastic modulus $(\varepsilon)$ (Table 1) can be calculated.

\section{Discussion}

The cell pressure probe is used widely in studies of stomatal function and plant cell water relations. Using the cell pressure probe, a previous study found that the volumetric elastic modulus can change from 2 to $40 \mathrm{MPa}$ and increased monotonically with cell turgor pressure [19]. Our results show that $\varepsilon$ decreased with $\mathrm{pH}$ from 8.60 to 6.50 when the cell turgor pressure and stomatal aperture were similar. A lower $\varepsilon$ value can help the guard cells to moving easier. This information is important for the development of mechanistic

Table 1 The $\varepsilon$ of the guard cell wall in epidermal strips after incubation for $30 \mathrm{~min}$ in light at $\mathrm{pH} 8.60$ and 6.50

\begin{tabular}{cccc}
\hline $\mathrm{pH}$ & Stomatal apertures $(\mu \mathrm{m})$ & $P(\mathrm{MPa})$ & $\varepsilon(\mathrm{MPa})$ \\
\hline 8.60 & 8.34 & 0.228 & 7.098 \\
6.50 & 9.76 & 0.244 & 5.690 \\
\hline
\end{tabular}



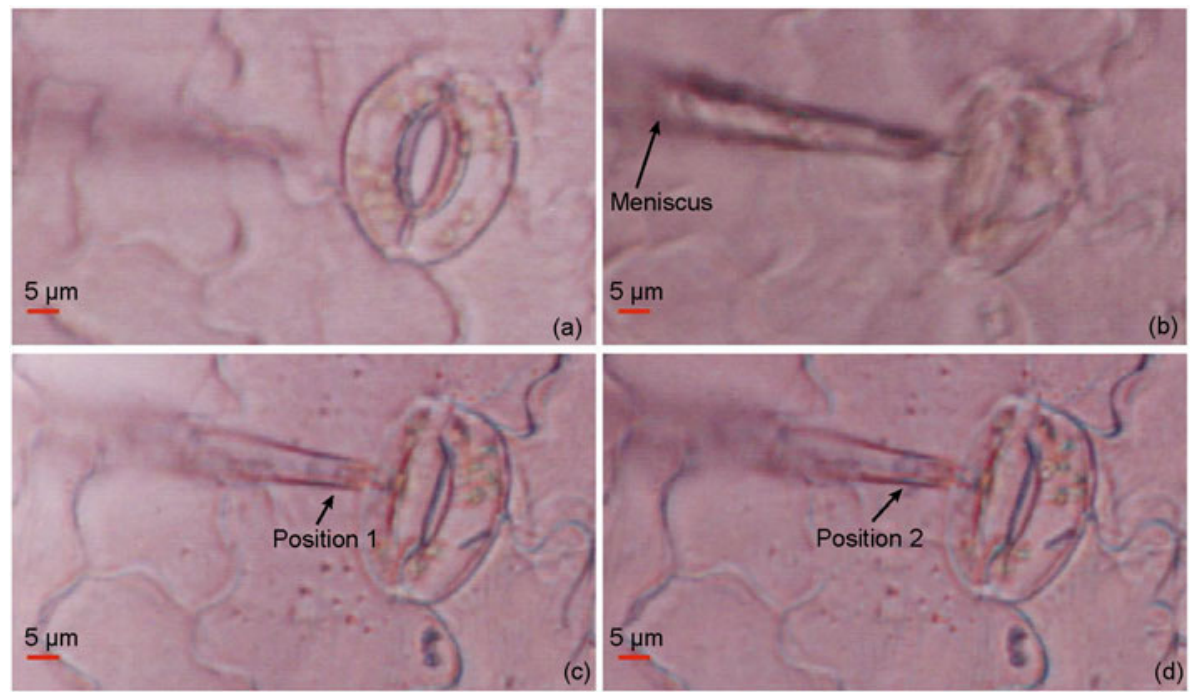

Figure 1 Measurement of the volumetric elastic modulus of the guard cell wall at $\mathrm{pH}$ 8.60. (a) The stomatal aperture and guard cell volume measurement; (b) meniscus acquisition; (c) and (d) positions 1 and 2 of the meniscus for measurement of volumetric elastic modulus.
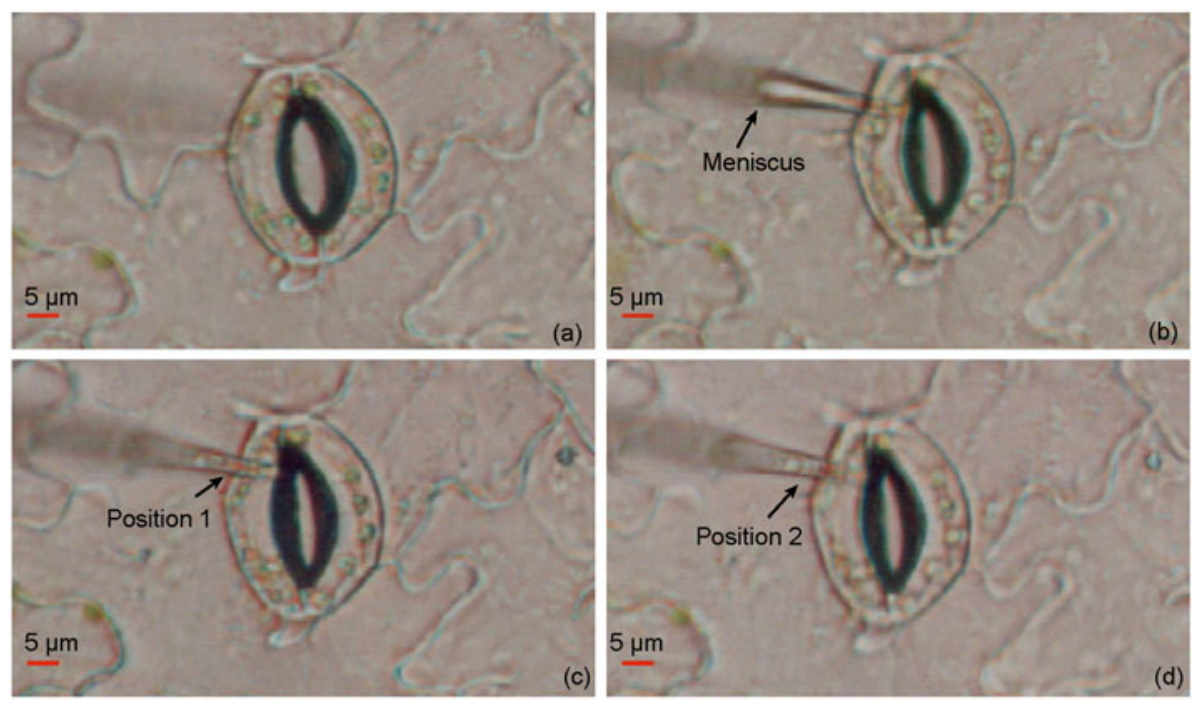

Figure 2 Measurement of volumetric elastic modulus of the guard cell wall at $\mathrm{pH}$ 6.50. (a) Stomatal aperture and guard cell volume measurement; (b) meniscus acquisition; (c) and (d) positions 1 and 2 of the meniscus for measurement of volumetric elastic modulus.

models of stomatal movement.

$\mathrm{pH}$ is a well-known cell signal [1] and can induce stomatal opening [20]. A lower $\mathrm{pH}$ value can stimulate expansin activity [21]. Expansin unlocks the network of wall polysaccharides and increases cell wall elasticity. Therefore, expansin may play a role in stomatal movement through regulation of the volumetric elastic modulus of the guard cell wall.

We thank Prof. Ernst Steudle (University of Bayreuth, Germany) and Dr. Qing Ye (University of Bayreuth, Germany) for critical suggestions and helpful advise on operation of the cell pressure probe. We are grateful to Prof. WANG XueChen for providing the cell pressure probe. This work was supported by the National Natural Science Foundation of China (39870075 and 39600090).
1 Hetherington A M, Woodward F I. The role of stomata in sensing and driving environmental change. Nature, 2003, 424: 901-908

2 Fischer R A. The relationship of stomatal aperture and guard-cell turgor pressure in Vicia faba. J Exp Bot, 1973, 24: 387-399

3 Aylor D E, Parlange J Y, Krikoria A D. Stomatal mechanics. Am J Bot, 1973, 60: 163-171

4 Wu H I, Sharpe P J H. Stomatal mechanics II: Material properties of guard cell walls. Plant Cell Environ, 1979, 2: 235-244

5 Sharpe P J H, Wu H I. Stomatal mechanics: Volume changes during opening. Plant Cell Environ, 1978, 1: 259-268

6 Wu H, Sharpe P J H, Spence R D. Stomatal mechanics. III. Geometric interpretation of the mechanical advantage. Plant Cell Environ, 1985, 8: 269-274

7 Jones L, Milne J L, Ashford D, et al. Cell wall arabinan is essential for guard cell function. Proc Natl Acad Sci USA, 2003, 100: 1178311788

8 Majewska-Sawka A, Munster A, Rodriguez-Garcia M I. Guard cell wall: Immunocytochemical detection of polysaccharide components. 
J Exp Bot, 2002. 53: 1067-1079

9 Zhang X Q, Wei P C, Xiong Y M, et al. Overexpression of the Arabidopsis $\alpha$-expansin gene AtEXPA1 accelerates stomatal opening by decreasing the volumetric elastic modulus. Plant Cell Rep, 2010, 30: 27-36

10 Zimmermann U, Husken D. Theoretical and experimental exclusion of errors in the determination of the elasticity and water transport parameters of plant cells by the pressure probe technique. Plant Physiol, 1979, 64: 18-24

11 Franks P J. Use of the pressure probe in studies of stomatal function. J Exp Bot, 2003, 54: 1495-1504

12 Steudle E. Pressure probe techniques: Basic principles and application to studies of water and solute relations at the cell, tissue, and organ level. In: Smith J A C, Griffiths H, eds. Water Deficits: Plant Responses from Cell to Community. Oxford: Bios Scientific Publishers, 1993. 5-36

13 Tomos A D, Leigh R A. The pressure probe: A versatile tool in plant cell physiology. Ann Rev Plant Physiol Plant Mol Biol, 1999, 50: $447-472$

14 Tomos D. The plant cell pressure probe. Biotechnol Lett, 2000, 22:
$437-442$

15 Wilkinson S, Davies W J. Xylem sap pH increase: A drought signal received at the apoplastic face of the guard cell that involves the suppression of saturable abscisic acid uptake by the epidermal symplast. Plant Physiol, 1997, 113: 559-573

16 Bacon M A, Wilkinson S, Davies W J. pH-regulated leaf cell expansion in droughted plants is abscisic acid dependent. Plant Physiol, 1998, 118: 1507-1515

17 MacRobbie E A C. Signal transduction and ion channels in guard cells. Philos Trans R Soc Lond B Biol Sci, 1998, 353: 1475-1488

18 Philip J. The osmotic cell, solute diffusibility, and the plant water economy. Plant Physiol, 1958, 33: 264

19 Franks P J, Buckley T N, Shope J C, et al. Guard cell volume and pressure measured concurrently by confocal microscopy and the cell pressure probe. Plant Physiol, 2001, 125: 1577-1584

20 Bittisnich D J, Entwisle L, ONeales T F. Acid-induced stomatal opening in Vicia faba L. and the role of guard cell wall elasticity. Plant Physiol, 1987, 85: 554-557

21 Cosgrove D J. Loosening of plant cell walls by expansins. Nature, 2000, 407: 321-326

Open Access This article is distributed under the terms of the Creative Commons Attribution License which permits any use, distribution, and reproduction in any medium, provided the original author(s) and source are credited. 